Hydrobiologia (2014) 734:125-141

DOI 10.1007/s10750-014-1874-9

\title{
Comparing aspirations: intercalibration of ecological status concepts across European lakes using littoral diatoms.
}

Martyn Kelly ${ }^{1}$, Gorazd Urbanic ${ }^{2,3}$, Eva Acs ${ }^{4}$, Vincent Bertrin ${ }^{5}$, Luc Denys ${ }^{6}$, Maria Kahlert ${ }^{7}$, Satu Maaria Karjalainen ${ }^{8}$, Bryan Kennedy ${ }^{9}$, Aldo Marchetto ${ }^{10}$, Soizic Morin ${ }^{5}$, Joanna Picinska-Fattynowicz ${ }^{11}$, Sandra Poikane ${ }^{21}$, Joerg Schoenfelder ${ }^{13}$; Ilka Schoenfelder ${ }^{13}$, Gabor Varbiro ${ }^{14}$

${ }^{1}$ Bowburn Consultancy, 11 Monteigne Drive, Bowburn, Durham DH6 5QB, UK

${ }^{2}$ Institute for Water of the Republic of Slovenia, SI-1000 Ljubljana, Slovenia

${ }^{3}$ University of Ljubljana, Biotechnical Faculty, Department of Biology, SI-1000 Ljubljana, Slovenia

${ }^{4}$ Danube Research Institute, Hungarian Academy of Sciences, Centre for Ecological Research, 2131 Göd, Javorka S. u. 14, Hungary

${ }^{5}$ Irstea, UR REBX, 50 avenue de Verdun, F-33612 Cestas, France. ${ }^{4}$

${ }^{6}$ Research Institute for Nature and Forest (INBO), Kliniekstraat 25, 1070 Brussels, Belgium.

${ }^{7}$ Department of Aquatic Sciences and Assessment,Swedish University of Agricultural Sciences, PO Box 7050, SE 75007 Uppsala, Sweden. ${ }^{8}$

${ }^{8}$ Finnish Environment Institute (SYKE), P.O.Box 413, FI-90014 University of Oulu, Finland

${ }^{9}$ EPA, John Moore Road, Castlebar, Co. Mayo, Ireland.

${ }^{10}$ CNR Institute of Ecosystem Study, Largo Tonolli 50, 28922 Verbania Pallanza, Italy

${ }^{11}$ Institute of Meteorology and Water Management, Wrocław Branch, Department of Ecology,Parkowa 30, 51-616 Wrocław, Poland. 
${ }^{12}$ European Commission, Joint Research Centre, Institute for Environment and Sustainability, Ispra, Italy

13 ,

${ }^{14}$ Balaton Research Institute, Hungarian Academy of Sciences, Centre for Ecological Research, 8237 Tihany, Klebelsberg K. u. 3, Hungary

\begin{abstract}
Eleven European countries participated in an exercise to harmonise diatom-based methods used for status assessment in lakes. Lakes were divided into low, medium and high alkalinity types for this exercise. However, it was not possible to perform a full intercalibration on low alkalinity lakes due to the short gradient and confounding factors. Values of the Trophie Index were computed for all samples in order that national datasets could all be expressed on a common scale. Not all participants had reference sites against which national methods could be standardised and, therefore, a Generalised Linear Modelling approach was used to control the effect of national differences in datasets. This enabled the high/good and good/moderate status boundaries to be expressed on a common scale and for deviations beyond \pm 0.25 class widths to be identified. Those countries which had relaxed boundaries were required to adjust these to within \pm 0.25 class widths whilst the intercalibration rules allowed those countries with more stringent and typological differences between countries, there was broad agreement on the characteristics of high, good and moderate status diatom assemblages, and the exercise has ensured consistent application of Water Framework Directive assessments around Europe.
\end{abstract}

boundaries to retain these. Despite biogeographicalntroduction

European environmental legislation such as the Water Framework Directive (WFD, European Union, 2000) operates within a system of governance known as "subsidiarity", which leaves the details of implementation up to individual member states. As a result, some 297 different methods have been developed and adopted by member states to demonstrate compliance with the ecological conditions set out in the WFD (Birk et al., 2012). In order to ensure that all member states have interpreted the Directive in a consistent manner, the WFD also stipulates that an intercalibration exercise be performed. This aims to harmonise national approaches to defining those points along the ecological condition gradient which are most important, from the point of view of decision making within the WFD. Ensuring a consistent approach to defining these points means that all member states of the EU share a common ambition, with respect to the state of surface water (Birk et al., 2013). 
"Macrophytes and phytobenthos" is one of the biological quality elements (BQEs) whose condition contributes to evaluations of "ecological status" in rivers and lakes, with "good status" (equating to just a slight change from the unimpacted condition) being the target for all surface water bodies by 2015. In practice, most countries perform separate evaluations of macrophytes and phytobenthos, with diatoms being used widely as proxies of phytobenthos. An intercalibration of national methods for using diatoms in central European rivers was reported by Kelly et al. (2009); similar intercalibrations for rivers elsewhere in Europe were also performed, the outputs of which became legally-binding on the countries involved (European Commission, 2008).

A number of problems were encountered during this work, several of which were common to intercalibrations of other groups of organisms (Birk et al., submitted). These included finding unambiguous definitions of the unimpacted condition of rivers (Pardo et al., 2012; Kelly et al., 2012) as well as variation between national data sets, part of which probably reflects biogeographical factors but differences in methodology may also play a role, despite all participants adhering to common standards for sampling and analysis (CEN, 2003; 2004). Kahlert et al. (2012) noted variation between analyses in a ring test persisted even after taxonomic harmonisation which may, under some circumstances, override the effect of continent scale biogeographical variation in determining monitoring outcomes (Kelly et al., 2012).

This paper describes an intercalibration exercise performed on diatom-based methods for assessing the ecological status of European lakes. The general approach was similar to that adopted for rivers (Kelly et al., 2009) but takes into account developments in the intercalibration procedures to address these issues. National methods should be tuned to optimise the relationship between the diatom assemblage and pressure gradient for a country. However, because many of the species (or species aggregates) are widely distributed across Europe, there should be sufficient similarities between these individual relationships that a broader trophic response relationship should emerge. Put simply, we are asking whether biologists from Ireland and Slovenia (the north-westerly and south-easterly extremes of participants) could look down a microscope and arrive at similar judgements about the ecological status of a sample originating from Finland (the north-easterly extreme). If this is possible, then we can be confident that, for this group of organisms at least, the WFD is being implemented in a consistent manner across the EU.

\section{Methods}

\section{The EU intercalibration exercise}

As intercalibration is a formal requirement of the WFD, a standard methodology, applicable to all types of water body and all BQEs (summarized in Birk et al., 2013) has to be adopted. Various options are available, depending on the similarities between national methods and the availability of reference sites. In the case of benthic diatoms, data are collected by very similar means by all participating countries, permitting an "indirect comparison" (Birk et al., 2013) whereby values computed using the national indices are each converted to a common metric. A regression between national and common metrics then 
allows values for status class boundaries to be expressed on a common scale. Boundary bias is evaluated as the difference between the national boundary and the average of all participating countries and is regarded as acceptable if the national boundary falls within \pm 0.25 class widths of the average.

Countries whose boundaries are lower than 0.25 class widths must adjust these to be within \pm 0.25 class widths; however, those with boundaries greater than 0.25 class widths are allowed to retain these.

Because ecological status is expressed as Ecological Quality Ratios (EQRs: defined as the observed state / expected state), there is an implicit assumption that all countries are able to make robust predictions of the expected (i.e. unimpacted) state for the water body in question. In practice, this has proved to be very difficult (see Pardo et al., 2012) and procedures have also been developed which allow comparisons in the absence of reference conditions. These are alternative benchmarking (when datasets were calibrated against a similar (low) level of impairment) and continuous benchmarking, where biological differences between national datasets were established by regression analysis, and an appropriate "offset" applied to each national dataset to bring it into line (Birk et al., 2013).

\section{Datasets}

11 countries took part in this exercise (Table 1). Each submitted data from national monitoring or method development programs. Diatom samples were collected from the littoral zones of lakes, sampled from either submerged stones or macrophytes, following CEN (2003); these were then processed in the laboratory to yield permanent slides from which at least 300 diatoms were named (mostly to species) and counted (CEN, 2004). Taxonomy was based on Krammer and Lange-Bertalot (1986-1991) and subsequent publications, following national conventions. As this paper does not directly compare composition, instead focusing on metric values, the taxonomic conventions described in Kelly and Ector (2012) and Kahlert et al. (2012) are not necessary, and any systematic variation arising from different approaches to taxonomy will be included in the national offsets described below.

National methods fall into one of four types:

1. indices based on the weighted average equation of Zelinka \& Marvan (1961) and optimised against a stressor gradient (e.g. Lake Trophic Diatom Index, LTDI, Bennion et al., 2012);

2. indices based on the relative proportions of taxa associated with unimpacted ("reference") and impacted conditions (e.g. PSIAD: VMM, 2009);

3. multimetrics based on a combination of these approaches (e.g. PHYLIB, Schaumburg et al., 2004); and,

4. other methods (e.g. Indice Biologique Diatomique, Coste et al., 2009, AFNOR NF T90-354, 2007). 
Methods of Belgium (Flanders), Germany, Hungary, Ireland, Poland and UK were developed specifically for lakes whilst those of Finland, France, Sweden and Slovenia were originally developed for rivers but have statistically significant relationships with pressure gradients in lakes (e.g. Cellamare et al. 2012).

Lakes were classified into an appropriate "Geographical Intercalibration Group" and "Type" following ECOSTAT (2004). However, some factors used to define types (e.g. maximum depth) are less relevant for littoral-dwelling organisms and a simpler typology was adopted here, with lakes defined as either "low alkalinity" $\left(<0.2\right.$ meq L $\left.^{-1}\right)$, “moderate alkalinity" $\left(\geq 0.2,<1\right.$ meq L $\left.^{-1}\right)$ or "high alkalinity" $\left(\geq 1\right.$ meq L $\left.^{-1}\right)$.

\section{Reference conditions}

Lakes were deemed to be in reference condition if the following criteria applied:

1. no point sources of pollution;

2. population density $<15$ people per square kilometre;

3. $<0.4 \%$ artificial land use within catchment;

4. $<20 \%$ agriculture in the catchment, not adjacent to lake (low-intensity stock raising on semi-natural landscapes excluded)*;

5. $<10 \%$ of lake shoreline is artificial*;

6. no alteration of natural lake hydrology (i.e. no dams or similar structures);

7. no introduction of carp or other bottom-feeding fish;

8. no intensive (commercial) fishing.

Most of these criteria apply to whole lakes. For the agriculture and artificial shoreline criteria, samples were accepted if the sites were well away from such influence. The screening criteria make no explicit reference to aerial deposition of pollutants; however, those countries with lakes with very soft water did remove any which showed obvious signs of acidification. (Maria, Bryan, Satu-Maaria, is this true?)

\section{Intercalibration metric}

The same principle was adopted here as for the river phytobenthos intercalibration exercise, with an "intercalibration metric" calculated on all national datasets to allow national boundaries to be converted, via linear regression, to a common scale (Kelly et al., 2009). For the river phytobenthos 
intercalibration exercise, the phytobenthos intercalibration metric (pICM) was the average of two widely-used metrics: the Indice de Polluosensibilite Specifique (IPS: Coste in CEMAGREF, 1982) and Trophieindex (TI: Rott et al., 1999). However, the IPS is effective over a wide range of water quality, extending into highly "saprobic" conditions, rarely found in lakes. In practice, only about half the IPS scale was used and, in some cases this resulted in a low slope between pICM and national metrics. As the optimum conversion between national metrics and intercalibration metrics requires a slope approaching 1 , inclusion of the IPS reduced the sensitivity of the intercalibration and, for this reason, the lake phytobenthos intercalibration metric is based on the TI alone.

An Ecological Quality Ratio (TI-EQR) was calculated as (4 - observed TI)/(4 -expected TI) for each sample, where "expected TI" was the average of national means values of the $\mathrm{TI}$ for all countries with reference sites, as defined above. A separate expected $\mathrm{TI}$ was calculated for each of the three types using $\mathrm{TI}=$ 1.02 for LA lakes, 1.38 for MA lakes and 1.88 for HA lakes.

Continuous benchmarking was done using a General Linear Model (GLM) in SPSS Statistics version 17.0 (SPSS Inc. 2008). In the model, TI-EQR was used as a dependent variable, member state as a random variable and the logarithmic value of total phosphorus (log TP) as the covariate. Analyses were conducted separately for high alkalinity (HA) lakes and moderate alkalinity (MA) lakes.

\section{Distribution of taxa along the EQR gradient}

The lake intercalibration database was used to calculate TI_EQR for all samples, and these values were then adjusted by the national offsets used in the boundary comparison.

The TI_EQR, adjusted by the national offsets, represents a consensus view of "ecological status" as most national methods have a significant relationship with this metric. The relative abundance of common taxa from all moderate and high alkalinity lakes in the database was then plotted against this adjusted EQR scale. Low alkalinity lakes were not included in this exercise due to the potentially confounding impact of low pH on the relationship between diatom assemblages and TP. There is interdependence between " $x$ " and " $y$ " on these plots, which simply visualise how properties which contribute to the EQR calculation vary along the gradient.

Note, too, that the limited number of Poor and Bad status sites, particularly for moderate alkalinity, means that the decline in some taxa below Moderate status may be an artefact of the dataset, rather than a genuine biological effect. Also, this analysis considers only the predominant nutrient gradient and other types of pressure (e.g. heavy metals, pesticides) may exert different responses on some taxa. Taxa names generally refer to aggregates, following practices in Kahlert et al. (2012) and Kelly and Ector (2011). The association of taxa with particular status classes was investigated by Indicator Species Analysis (Dufrène \& Legendre 1997) implemented in PC-ORD 5.0 (McCune \& Mefford 1999). 


\section{Results}

\section{Reference conditions}

Lakes at reference conditions were not evenly distributed between either countries or types. Two countries, BE-FL and HU, had no reference sites at all whilst, for other countries, the number of lakes which fulfilled the criteria was low, particularly for MA lakes where there were, on average, only 2.6 lakes per country (excluding those with no reference sites). The situation was better for LA and MA lakes, with averages of 8.5 and 9.8 respectively, though most countries compensated, to some extent, by including multiple samples from water bodies into their datasets. Again, MA lakes had the fewest samples per country, with just 5.2, whilst LA and HA lakes had 40 and 30 samples per country respectively. Overall, the shortcomings of the reference dataset led to a decision to adopt continuous benchmarking rather than attempt to use reference conditions as a benchmark.

\section{Regressions}

In order to successfully intercalibrate a national method there needs to be a significant relationship between the national metric and both the intercalibration metric and the pressure gradient (expressed here as log total phosphorus, TP: Table 2). For low alkalinity lakes, the relationship with the pressure gradient was significant for all countries except Sweden; however, the data cloud has a " $Y$ "-shape (Fig. 1a): the upper branch shows little response to increasing nutrient levels, whist the lower branch shows decreasing TI-EQR values as TP increases. Preliminary investigations suggest that this is not easily explainable by typological factors (both branches include strongly humic lakes) but the "upper" group tends to have lower pH (6-6.4) than the "lower" group (pH 6.5-6.9 - based on FI data).

For moderate alkalinity lakes, all relationships between national metrics and pressure variables were significant with the exception of Germany and Italy, both of which had only very small datasets spanning a small part of the total gradient for this particular type. The relationship between TI-EQR and log TP is significant for France only if ac Carcans-Hourtin is excluded. This is a lowland shallow reference lake albeit with both relatively high TP (and a high N:P ratio) and very high values for TI-EQR. Overall, there is some heteroscedasticity in the relationship (Fig. 1b), with a wide range of values of ICM recorded at low pressure, and a possible response threshold at about $10 \mu \mathrm{g} \mathrm{L}^{-1} \mathrm{TP}$. However, few countries had data that spanned the whole gradient and there are few sites with $>100 \mu \mathrm{g} \mathrm{L}^{-1} \mathrm{TP}$.

All relationships between diatom metrics and log TP in high alkalinity lakes were significant, again with the exception of Italy, probably due to the small size of its national dataset. Samples from Slovenia are clustered at the top left hand corner of the graph (Fig. 1c), whilst there are also a number of outliers for Poland which cannot be explained by any typological factors. 
The weak relationships, and suspicions of confounding factors, within the low alkalinity dataset led to no further action at this point. Generalised linear models were calculated for the moderate and high alkalinity types, in order that offsets could be calculated which would account for variability introduced into the regressions by "national" effects (Table 3). Figs. 1c and 1e show these effects for moderate and high alkalinity respectively. For moderate alkalinity, subtracting the offset improved the fit of the whole dataset to $\log$ TP from $r^{2}=0.35$ to 0.53 whilst, for high alkalinity, the improvement was lower, from $r^{2}=$ 0.41 to 0.45 . Lac Carcans-Hourtin remained an outlier in the moderate alkalinity dataset, as did some Polish sites in the high alkalinity dataset, even after adjustments, whilst Slovenian sites moved closer to the main trend of the dataset.

\section{Intercalibration}

Having established relationships between each national method and the intercalibration metric, using the offset to account for national differences, the next stage was to convert national boundaries for high/good and good/moderate status to equivalent values of the TI-EQR (Table 4), then to examine the deviation of these from the common view (expressed as the mean of the TI-EQRs for all participating countries). For high/good status in moderate alkalinity lakes, Belgium (Flanders) had highly precautionary boundaries whilst Sweden and UK had relaxed boundaries (where each country is allowed \pm 0.25 class deviation). For good/moderate status, Belgium (Flanders) and Ireland are both stringent whilst Finland is relaxed (Fig. 2a \& b). Countries are allowed to retain stringent boundaries, but those with relaxed boundaries must adjust these to within \pm 0.25 class widths. Those countries with stringent and relaxed boundaries therefore examined their national datasets to ensure that outcomes were robust. In the case of Ireland, for example, the data spanned a short gradient, mostly at high and good status, and the Irish dataset was therefore supplemented with data from UK lakes to produce a dataset spanning a longer gradient in order to check calculations. The Irish boundary was, however, still precautionary, even after this and both they and Belgium (Flanders) exerted their right to retain these values. The implications of these decisions on those countries with relaxed boundaries was examined but even if both Belgium (Flanders) and Ireland had adjusted their boundaries, Finland, Sweden and UK would still have relaxed boundaries and, as a result, all made adjustments in order to bring their boundaries into line.

A similar process was enacted for high alkalinity lakes (Fig. 2c \& d). Here, Slovenia was stringent for the high/good boundary whilst Germany, Slovenia and UK had stringent good/moderate boundaries whilst Poland had relaxed boundaries for $\mathrm{H} / \mathrm{G}$ and $\mathrm{G} / \mathrm{M}$ and Hungary had a relaxed $\mathrm{G} / \mathrm{M}$ boundary only. Again, an iterative process was undertaken to ensure that the relationships for each participating country were robust, and testing the consequences of adjusting stringent boundaries downwards before Hungary and Poland adjusted their boundaries to within \pm 0.25 classes.

\section{Distribution of taxa along the EQR gradient}

Most of the abundant taxa were found across the EQR gradient, albeit with some clear patterns in relative abundance emerging between status classes for both types which was reflected by significant differences in indicator values (Tables 5 \& 6). Achnanthidium minutissimum sensu lato, for example, is the most commonly recorded taxon in the database, often forming more than $40 \%$ of the total in high and good status sites, but declining in relative abundance 
as EQR decreased, and there were few sites with >20\% A. minutissimum ag. at moderate status or below. Other taxa with a predominately high/good distribution included Brachysira microcephala/vitrea (more abundant in MA than in HA lakes), Gomphonema angustum ag. and Tabellaria flocculosa (the latter, again, more common in MA than in HA lakes).

Other taxa which tended to increase as EQR decreased were Amphora pediculus, Cocconeis placentula ag., Gomphonema parvulum and Nitzschia amphibia. C. placentula can live as both directly on rocks and as an epiphyte, and the increase may, in part, reflect an increase in filamentous green algae as EQR decreases. The increase in Nitzschia amphibia reflects a general pattern of increasing motile diatoms as EQR decreases (Fig. 3).

\section{Discussion}

\section{General comments}

The hypothesis outlined in Introduction appears to hold: this study shows good pan-European agreement in response of diatoms to the predominant eutrophication gradient, with about half of total variation being explained by a simple linear regression between a common index (TI-EQR) and log total phosphorus. There is still scope for local fine-tuning of indices but the relationship is strong enough to allow valid comparisons to be made between countries.

Though the Annex V of the WFD refers sto the assessment of macrophytes and phytobenthos in lakes, only 12 of the 27 member states of the EU took part in this intercalibration exercise. Of the others, three include filamentous algae in their macrophyte survey methods whilst the remainder do not consider phytobenthos at all (Kelly, submitted). Several countries argued that their macrophyte assessment systems were adequate to fulfil their obligations, although few presented any data to support this assertion (ref to IC tech reports). Even where macrophyte and phytobenthos metrics were strongly correlated there are two flaws with this position:

1. macrophytes and phytobenthos will respond at different rates to changes in conditions within lakes, with phytobenthos presumed to respond more quickly and thus offer early indications of both deterioration and improvements in status (Schaumburg et al., 2004, Pall \& Moser 2009);

2. macrophytes and phytobenthos respond differently to pressures and failure to assess both may reduce the ability to untangle situations where several stressors are acting simultaneously on a water body. (Schneider et al 2012).. Because macrophytes are highly sensitive to hydromorphology (Hellsten \& 
Riihimäki 1996, Mjelde et al 2012), we anticipate situations in lakes with extensive physical modification where the ability of the macrophyte flora to respond to changes in nutrient conditions may be compromised.

Parker and Maberley (2000) present a convincing study of the benefits of phosphorus reduction in Windermere (UK), by evaluating changes in filamentous algae in the littoral zone; it is sobering to realise that such obvious changes would not just be missed by the 12 assessment systems that have no consideration of phytobenthos at all, but also by five of the countries included in this exercise but who lack parallel assessment of filamentous algae in their macrophyte assessment systems.

\section{Use of metrics developed for rivers in lakes}

Four countries involved in this exercise used metrics originally developed for rivers as part of their assessment of ecological status in lakes. Whilst the strongest correlations with the pressure gradient were for BE-FL's metric developed specifically for lakes (Table 2), strong correlations were also observed in some cases when metrics originally developed for rivers were used in lakes. For example, Finland explained over $70 \%$ of the variation in the main pressure gradient in MA lakes using the IPS, designed originally for use in rivers (Coste, in CEMAGREF, 1982). This relationship is stronger than that for several metrics developed specifically for rivers (Table 2) though several other factors including the length of the gradient interact to determine the apparent strength of these relationships. Several other studies have also demonstrated strong relationships between diatom metrics originally developed for rivers to lake environment (Poulíčková et al., 2004; Kitner \& Poulíčková, 2003; Blanco et al., 2004; Cejudo-Figueiras et al., 2010;, 2011; Ács et al 2005, Bolla et al 2010). Many of the taxa encountered during this study (Table 5) are also common in rivers, reflecting the similarities in physical, chemical and biological stresses encountered by diatoms in the littoral zones of lakes and in benthic habitats in rivers (Cantonati \& Lowe, 2014). However, there are also limitations associated with the use of metrics developed for rivers, and some diatom species do have distinct preferences for lakes over rivers, CejudoFigueiras et al. (2011) noted that one of the indices they tested (CEC; Descy \& Coste 1991) does not include Aulacoseira subarctica, Fragilaria bicapitata or Navicula cryptocephala, all of which are typical of shallow lakes of NW Spain. Kitner \& Poulícková 2003) also encountered problems when using the TI In Czech fishponds, noting that the absence of Aulacoseira ambigua and centric diatoms from this metric led to overestimations of lake quality. However, this introduces a further problem, as both A. subarctica and A. ambigua, along with many other centric diatoms are predominately planktonic in habit. Should they play a role in the assessment of the condition of the phytobenthos? Indeed, if there are parallel assessments of phytoplankton composition then these taxa may make two contributions to the final assessment of the water body. On the other hand, other Aulacoseira species (e.g. A. crenulata (Ehrenberg) Thwaites 1848) appear to have a benthic or tychoplanktonic habit (ref) whilst, in many cases, the precise habitat requirements are insufficiently known to be able to make crisp distinctions between "benthic" and "planktonic" taxa in all cases. It is also difficult to disentangle issues regarding the taxa which contribute to river versus lake metrics with problems associated with adapting indices developed in one geographic region (e.g., Austria or the Netherlands) to other parts of Europe (Spain or Hungary). The UK metrics used in this study has strong correlations with both the river metric developed for the same 
region (Bennion et al., 2014) and the TI (Table 2), suggesting that the problems encountered are more likely to reflect differences in the taxon list of the index rather than the fundamental performance of the index.

\section{Response of diatoms in low alkalinity lakes}

The relatively weak relationships in low alkalinity lakes stands in contrast to the situation for moderate and high alkalinity lakes. Low alkalinity lakes in this study were restricted to Scandinavia, UK and Ireland and, generally, are situated in remote regions suited only to forestry or low intensity pastoral agriculture. Consequently, it is hard to capture "eutrophication" gradients that are as long as for moderate and high alkalinity lakes. However, this artefact of the dataset is further complicated by the presence, in many cases, of a confounding acidity gradient, itself composed of both "natural" and "anthropogenic" components (Fig. 1a). Schneider et al. (2013) demonstrate the problems of evaluating nutrient status in the presence of a strong acid pressure and although this paper deals with rivers rather than lakes, the principles should be transferable. Juggins (2013) points out other issues associated with interpretation of univariate responses in the presence of confounding variables. Although we lack the supporting data necessary to evaluate the extent to which the effects observed in Fig. 1a are due to anthropogenic acidification, we suspect a mix of factors.

Interactions beween benthic algae and low level nutrient enrichment will be complicated: such lakes may be N-limited (Maberley et al., 2003), and the N load may be derived, at least in part, from atmospheric deposition, even as $\mathrm{S}$ deposition is decreasing (Flower et al., 2010).).). Moreover, one effect of acidification will be to reduce phytoplankton densities (Battarbee et al., 1999) and colouring by humic substances (Monteith et al., 2007), potentially increasing transparency and encouraging benthic productivity. Conversely additional nutrients in the absence of acidification may be manifest first in phytoplankton productivity and assemblage changes, rather than in changes to the benthic assemblage (Bennion et al., 2004). There is, in other words, no a priori case for benthic algae in low alkalinity lakes necessarily being the most sensitive indicator of nutrient changes.

\section{Implications for biogeography and diatom ecology}

The consistent pan-European response might appear surprising, bearing in mind the scale of cryptic diversity and endemism discovered within diatoms in recent years (Mann et al., 2007; Trobajo et al., 2009). This finding is, however, consistent with Kelly et al. (2012) and suggests that this type of status assessment is robust. In broad terms, the scenario presented in the introduction, that biologists from Ireland and Slovenia could look down a microscope and arrive at similar judgements about the ecological status of a sample originating from Finland would appear to be correct. This, in turn, lends weight to the use of diatoms as part of status assessment toolkits. However, we recognise that this approach glosses over many real albeit often subtlte differences amongst diatom species.

Until recently, many believed that most diatom species were widespread, or even cosmopolitan (e.g. Round, 1981). This, in turn, led to the use of diatom Floras outside the regions for which they were originally written and, in particular, the de facto adoption of the Susswässerflora von Mitteleuropa (Hustedt, 
1930, Krammer and Lange-Bertalot, 1986, 1988, 1991a, b) throughout Europe and beyond. Despite the growing evidence of endemism and cryptic variation (refs) many persist in using such volumes partly because the more recent taxonomic literature is often scattered between many monographs and journal articles. However, even if many of the names in the standard floras are, in effect, "operational taxonomic units" rather than true biological species, these at least provide a measure of consistency when considering pan-European datasets such as these.

s biogeographical and typological variants which are overlooked when complexes are merged into, in effect, "operational taxonomic units". At a practical level, cryptic diversity creates problems in ensuring consistent identification of the myriad newly-described taxa even by specialist diatomists (Kahlert et al., 2012). The onus, therefore, lies with individual member states to enact rigorous quality control to ensure consistency and to liaise with neighbouring states to ensure that identification is not a source of systematic error when water bodies that span national boundaries are assessed. The role that cryptic species may play in ecological status assessment is still an open question as very few studies have gone beyond documenting taxonomic variability. It is possible, as Kelly and Ector (2012) suggest, that many cryptic species are biogeographical and typological forms which all play similar roles in the functioning of aquatic ecosystems. It is also possible that cryptic forms may have different preferences for pressure variables such as pH and TP yet still have little effect on ecological processes within littoral ecosystems. Yet the possibility that a shift between two subtly different forms within a complex either precipitates or indicates a significant shift in functioning must not be overlooked either. Without more detailed studies on the autecology of individual taxa within complexes it will not be possible to answer these questions.

All "shoehorn" to KLB "CENTRAL EUROPE" FLORA. Legacy of older era when "everything is everywhere" and floras regarded as applicable more widely than the region for which they were written. Current ev that "everything is everywhere" is challenged (refs) but legacy actually works to our advantage. Our experience is certainly that some things may be everywhere, others are not, and many groups still need more detailed work.

\section{Conclusions}

This study has demonstrated broad-scale agreement of approach between assessment methods used around Europe for assessing ecological status using diatoms. Whilst recognising that diatoms are only part of the phytobenthos, and taxonomic composition forms only part of the normative definition for the BQE macrophytes and phytobenthos, this is an encouraging start.

This exercise is part of a much broader process by which all BQEs across all water body types should have been intercalibrated following a standard procedure (Birk et al., 2013). This means not only that we have harmonised status class boundaries between participating countries for lake phytobenthos but that boundaries set for lake phytobenthos should be compatible with those of other BQEs in lakes and comparable with boundaries set for other BQEs in other water body types, all of which have been subject to the same procedures (Bennett et al., 2011; Birk et al., 2012; Poikane et al., 2010). The 
good/moderate boundary for a lake in the west of Ireland should, in theory at least, represent a similar level of ambition to the good/moderate boundary set for marine invertebrates in benthic habitats off the coast of Cyprus. Limitations encountered here such as a lack of reference sites and (in many cases) short gradients in some countries are common to many exercises (Birk et al., 2012, 2013). The outcome of this, and other completed intercalibration exercises is a « Decision » (EU, 2013) which makes the boundaries legallly binding on those member states involved.

The wide geographical extent of this exercise was, however, unusual. As discussed above, this reflects a measure of pragmatism in how many complexes of closely-related taxa were handled yet also the remarkably unified approaches adopted for the collection and analysis of samples (CEN 2003, 2004). In practice, biogeographical differences in some other groups (e.g. benthic invertebrates in rivers) are entangled with methodological differences, both in sampling and analysis (Bennett et al., 2011) which create greater problems in IC than encountered here.

What are the next steps: Only 11 out of 28 member states of the European Union were involved in this exercise, which means that over half the EU is not formally compliant. Several states argued that their macrophyte assessment systems were adequate to fulfil their obligations, although few presented any data to support this assertion (Poikane, 2013). For such an assumption to be valid, a strong correlation between macrophytes and phytobenthos EQRs would need to be demonstrated, though few states have produced such evidence (presumably believing that macrophytes alone are sufficient). Our belief is that macrophytes and phytobenthos provide complementary information and, more importantly, there will be situations where macrophytes cannot be used or where the faster response times of diatoms will provide information that macrophytes cannot offer (DeNicola \& Kelly, submitted) There should now be fewer impediments to countries adopting phytobenthos methods, with a standard metric, reference values and boundaries now avaiable for most Euroepan lake types as a result of this study. The applicability of this approach will need to be checked for each new country, particularly to ascertain whether there are any major constituents of the benthic flora that are overlooked by the TI. This provides an "off the shelf" method, which will enable the collection of robust assessment data which, in turn, will provide a foundation from which more locally-specific methods can be developed.

More generally, having established relationships between metrics and pressures, and harmonised boundaries, the focus should now shift to how metrics should be used to ensure that sites can be classified with high confidence. Assessment is, after all, just the first stage in the process of identifying water bodies in need of « programmes of measures " and variabiltiy, particularly around the good/moderate boundary, needs to be minimised if failing water bodies are to be correctly identified and prioritised. This study - and, indeed, the implementation of the WFD as a whole - takes place at a time of economic uncertainty for much of Europe which adds a greater incentive to ensure that public money is spent wisely. .

Comments on national policies ? Comments regarding the perspectives of this work? : 
- $\quad$ To go back to the introductive part "macrophytes + phytobenthos is one of the BQE"...: are phytobenthos based assessments compliant with macrophytes-based ones? (maybe you'll find some interesting things in the Cellamare et al paper attached) Are these methods complementary? Are they both needed (e.g. in case no macrophytes are present)? Which are the possible options for combination of the metrics?

- How do you imagine the next steps / use of the methods for i) MS that had a small dataset: can we expect that the relationships will still be OK with larger databases? I) MS that did not took part to the IC exercice: will they use the ICM? Can we expect that this will fit their regulatory requirements / correspond to what they consider as G status for ex?

Maybe this could be discuss with the hindsight you have from river IC?

Ind

- will there be some kind of comparison between ecology/preferenda of the same taxa in lakes and rivers?

- $\quad$ Do you have in the database "typical from lakes" $\rightarrow$ is it possible to extract from the database information about their ecological requirements?

Reasons for low alkalinity effects

Problems associated to reference conditions.

Differences between EQRs reflecting composition/structure vs trophic status.

\section{References - to follow}

AFNOR, 2007. Qualité de l'eau - Détermination de l'Indice Biologique Diatomées (IBD) - NF T90-354

Bennett et al. Invertebrate IC paper

Bennion, H., J. Fluin, and G. L. Simpson. 2004. Assessing eutrophication and reference conditions for Scottish freshwater lochs using subfossil diatoms. Journal of Applied Ecology 41:124-138. 
Birk, van Kouwen, Willby, 2012, harmonising bioassessmento f Danube

Cellamare M., Morin S., Coste M., Haury J. 2012. Ecological assessment of French Atlantic lakes based on phytoplankton, phytobenthos and macrophytes. Environmental Monitoring and Assessment 184, 4685-4708.

Coste, M., Boutry, S., Tison-Rosebery, J., Delmas F. 2009. Improvements of the Biological Diatom Index (BDI): Description and efficiency of the new version (BDI-2006). Ecological Indicators, 9(4), 621-650.

Birk S., Bonne W., Borja A., Brucet S., Courrat A., Poikane S., Solimini A., van de Bund W., Zampoukas N., Hering D. (2012) Three hundred ways to assess

Europe's surface waters: an almost complete overview of biological methods to implement the Water Framework Directive. Ecological Indicators 18: $31-41$.

Birk S., Willby N.J., Kelly M., Bonne W., Borja A., Poikane S., van de Bund W. Intercalibrating classifications of ecological status: Europe`s quest for common management objectives for aquatic ecosystems. Science of the Total Environment (submitted)

EC (2008) Commission Decision of 30 October 2008 establishing, pursuant to Directive 2000/60/EC of the European Parliament and the Council, the values of the Member State monitoring system classifications as a result of the intercalibration exercise 2008/915/EC. Official Journal of the European

Communities L332/20. European Commission, Brussels

Hellsten S. \& Riihimäki J. (1996) Effects of lake water level regulation on the dynamics of littoral vegetation in northern Finland. Hydrobiologia 340, 85-92

Juggins 2013

Mjelde M., Hellsten S., Ecke F. (2012) A water level drawdown index for aquatic macrophytes in Nordic lakes. Hydrobiologia. 10.1007/s10750-012-1323-6

Monteith, D.T., Stoddard, J.L., Evans, C.D., de Wit, H.A., Forsius, M., Høgåsen, T., Wilander, A., Skjelkvåle, B.L., Jeffries, D.S., Vuorenmaa, J., Keller, B., Kopácek, J. \& Vesely, J. (2007). Dissolved organic carbon trends resulting from changes in atmospheric deposition chemistry. Nature (London) 450: 537541. 
Pall, K. \& Moser, V. (2009) Austrian Index Macrophytes (AIM-Module 1) for lakes: a Water Framework Directive compliant assessment system for lakes using aquatic macrophytes.. Hydrobiologia 633, 83- 104.

Parker J.E \& Maberly S. C (2000) Biological response to lake remediation by phosphate stripping: control of Cladophora. Freshwater Biology 44, 303-309.

Round, E E., 1981. The ecology of algae Cambridge, 653 pp.

Schaumburg J., Schranz C., Hofmann G., Stelzer D., Schneider S., Schmedtje U. (2004) Macrophytes and phytobenthos as indicators of ecological status in German lakes - a contribution to the implementation of the water framework directive. Limnologica 34, 302-314.

Schneider S.C., Kahlert M., 1, Kelly M.G. (2013) Interactions between pH and nutrients on benthic algae in streams and consequences for ecological status assessment and species richness patterns. Science of the Total Environment 444, 73-84.

Schneider S.C., Lawniczak A.E., Picinska-Faltynowicz J., Szoszkiewicz K. (2012): Do macrophytes, diatoms and non-diatom benthic algae give redundant information? Results from a case study in Poland. Limnologica 42, 204-211.

Dufrêne M., Legendre P., 1997. Species assemblages and indicator species: the need for a flexible asymmetrical approach. Ecological Monographs 67: $345-$ 366.

Mann, D.G., Thomas, S.J. \& Evans, K.M. 2008 Revision of the diatom genus Sellaphora: a first account of the larger species in the British Isles. Fottea, Olomouc 8: 15-78.

McCune B., Mefford M.J., 1999. PC-ORD. Multivariate Analysis of Ecological Data.

Version 5.0. MjM Software, Gleneden Beach.

Poikane, Alves, Argiller ....2010 Defining chlorophyll a ref conditions Env managment

Trobajo, R., Clavero, E., Chepurnov, V.A., Sabbe, K., Mann, D.G., Ishihara, S. \& Cox, E.J. 2009. Morphological, genetic and mating diversity within the widespread bioindicator Nitzschia palea (Bacillariophyceae). Phycologia 48: 443-459 
VMM, 2009. Biological assessment of the natural, heavily modified and artificial surface water bodies in Flanders according to the European Water Framework Directive. September 2009. Available in Dutch and English. Vlaamse Milieumaatschappij, Erembodegem, Belgium. 
Table 1. Countries/regions participating in the lake phytobenthos intercalibration exercise, and their national methods. Further details of national methods can be obtained from http://www.wiser.eu/results/method-database/ LA: Low alkalinity $\left(<0.2\right.$ meq $\left.L^{-1}\right)$; MA, moderate alkalinity $(\geq 0.2,<1$ meq $\left.L^{-1}\right)$; HA: high alkalinity $\left(\geq 1\right.$ meq $L^{-1}$.

\begin{tabular}{|c|c|c|c|c|c|c|c|c|}
\hline \multirow{2}{*}{\multicolumn{2}{|c|}{$\begin{array}{c}\text { Member State and } \\
\text { abbreviation }\end{array}$}} & \multirow{2}{*}{ Method } & \multicolumn{3}{|c|}{ Samples (lakes) } & \multicolumn{3}{|c|}{ Reference samples (lakes) } \\
\hline & & & LA & MA & HA & LA & MA & HA \\
\hline Belgium (Flanders) & BE-FL & $\begin{array}{l}\text { Proportions of Impact-Sensitive } \\
\text { and Impact-Associated Diatoms } \\
\text { (PISIAD) }\end{array}$ & - & 79 (18) & $68(14)$ & - & $0(0)$ & $0(0)$ \\
\hline Germany & DE & $\begin{array}{l}\text { PHYLIB: Multi metric index for } \\
\text { Macrophytes and Phytobenthos }\end{array}$ & - & $14(3)$ & $698(119)$ & - & ? & $95(25)$ \\
\hline Finland & $\mathrm{FI}$ & $\begin{array}{l}\text { Preliminary classification is } \\
\text { based on IPS; moving to Finnish } \\
\text { Littoral Diatom Method in } \\
\text { future }\end{array}$ & $25(21)$ & $25(25)$ & - & $5(4)$ & $5(4)$ & - \\
\hline France & $\mathrm{FR}$ & $\begin{array}{l}\text { Indice Biologique Diatomées } \\
\text { (IBD2007) }\end{array}$ & - & $33(5)$ & - & - & $14(2)$ & - \\
\hline Hungary & $\mathrm{HU}$ & $\begin{array}{l}\text { Multimetric Index for Lakes } \\
\text { (MIL) }\end{array}$ & - & - & $84(\#)$ & - & - & $28(13)$ \\
\hline Ireland & IE & $\begin{array}{l}\text { Lake Trophic Diatom Index (LTDI } \\
\text { mark 1) }\end{array}$ & $45(22)$ & $34(14)$ & $120(62)$ & ? & $?$ & $28(13)$ \\
\hline Italy & IT & $\begin{array}{l}\text { Plans to adopt ICM at end of } \\
\text { exercise }\end{array}$ & - & $7(7)$ & $17(15)$ & - & $2(2)$ & $0(0)$ \\
\hline Poland & PL & $\begin{array}{l}\text { PL IOJ (multimetryczny Indeks } \\
\text { Okrzemkowy dla Jezior = } \\
\text { multimetric Diatom Index for } \\
\text { Lakes) }\end{array}$ & - & - & $156(134)$ & - & - & $11(10)$ \\
\hline Sweden & SE & $\begin{array}{l}\text { Indice de Pollusensibilité } \\
\text { Spécifique (IPS) }\end{array}$ & 32 (21) & $21(15)$ & $28(15)$ & ? & $2(2)$ & $14(12)$ \\
\hline
\end{tabular}


Slovenia

SI

Trophie Index (TI)

36 (3)

19(1)

Diatoms for Assessing River and

United Kingdom

Lake Ecological Quality (DARLEQ

$438(72)$

$201(40)$

$320(66)$

75(13)

3(3)

15(8) mark 2) 
Table 2. Relationships between national metrics and log Total Phosphorus and the intercalibration metric.

\begin{tabular}{|c|c|c|c|c|c|c|}
\hline \multirow[t]{2}{*}{ Country } & \multirow[t]{2}{*}{ Type } & \multicolumn{3}{|c|}{ Relationship with ICM } & \multicolumn{2}{|c|}{ Relationship with $\log _{10}$ TP } \\
\hline & & intercept & slope & $\mathbf{R}^{2}$. & Significance & $\mathbf{R}^{2}$ \\
\hline \multirow[t]{2}{*}{$\mathrm{BE}-\mathrm{FL}$} & HA & 0.152 & 1.01 & 0.769 & $P<0.001$ & 0.829 \\
\hline & MA & 0.007 & 1.190 & 0.800 & $P<0.001$ & 0.855 \\
\hline \multirow[t]{2}{*}{$\mathrm{DE}$} & $\mathrm{HA}$ & 0.529 & 0.50 & 0.598 & $P<0.001$ & 0.198 \\
\hline & MA & 0.825 & 0.090 & 0.064 & $P=0.802$ & 0.0055 \\
\hline \multirow[t]{2}{*}{$\mathrm{FI}$} & LA & 0.488 & 1.507 & 0.868 & $P=0.031$ & 0.299 \\
\hline & MA & 0.529 & 0.423 & 0.870 & $P<0.001$ & 0.719 \\
\hline \multirow[b]{2}{*}{$\mathrm{FR}$} & & & & & $P=0.606$ & $0.0055^{*}$ \\
\hline & MA & 0.601 & 1.593 & 0.826 & $P=0.091$ & $0.119 * *$ \\
\hline $\mathrm{HU}$ & HA & -0.576 & 1.905 & 0.759 & $P=0.014$ & 0.137 \\
\hline \multirow[t]{3}{*}{ IE } & LA & 0.51 & 0.439 & 0.098 & $P<0.0001$ & 0.3519 \\
\hline & HA & 0.303 & 0.748 & 0.786 & $P<0.001$ & 0.476 \\
\hline & MA & 0.302 & 0.628 & 0.589 & $P=0.023$ & 0.2929 \\
\hline IT & MA & 0.008 & 0.948 & 0.852 & $P=0.602$ & 0.0583 \\
\hline $\mathrm{PL}$ & $\mathrm{HA}$ & -0.008 & 0.985 & 0.644 & $P<0.001$ & 0.133 \\
\hline \multirow[t]{3}{*}{ SE } & LA & 0.380 & 0.634 & 0.164 & $P=0.184$ & 0.058 \\
\hline & HA & -0.187 & 1.25 & 0.402 & $P<0.001$ & 0.145 \\
\hline & MA & -0.409 & 1.349 & 0.550 & $P=0.045$ & 0.195 \\
\hline $\mathrm{SI}$ & HA & 0.320 & 0.858 & 0.884 & $P=0.002$ & 0.311 \\
\hline \multirow[t]{3}{*}{ UK } & LA & 1.210 & -0.275 & 0.051 & $P=0.022$ & 0.059 \\
\hline & HA & 0.320 & 0.717 & 0.877 & $P<0.001$ & 0.375 \\
\hline & MA & -0.182 & 1.054 & 0.759 & $P<0.001$ & 0.2907 \\
\hline
\end{tabular}

* includes Carcans-Hourtin; ** excludes Carcans-Hourtin 
Table 3. Common view and member-state specific mean Trophic index EQR values (TI_EQR) for high and moderate alkalinity lakes using General linear models.

Covariates appearing in the model are evaluated at $\log \mathrm{TP}=1.6665 \mathrm{mg} \mathrm{L}^{-1}$ for high alkalinity lakes and $1.3689 \mathrm{mg} \mathrm{L}^{-1}$ for moderate alkalinity lakes.

\begin{tabular}{|c|c|c|c|c|}
\hline \multirow[b]{2}{*}{ Member state } & \multirow[b]{2}{*}{ Mean TI_EQR } & \multirow[b]{2}{*}{ Std. Error } & \multicolumn{2}{|c|}{ 95\% Confidence Interval } \\
\hline & & & Lower Bound & Upper Bound \\
\hline \multicolumn{5}{|c|}{ High alkalinity } \\
\hline BE-FL & $0.719^{\mathrm{a}}$ & 0.042 & 0.637 & 0.800 \\
\hline $\mathrm{DE}$ & $0.775^{\mathrm{a}}$ & 0.014 & 0.748 & 0.803 \\
\hline $\mathrm{HU}$ & $0.862^{\mathrm{a}}$ & 0.026 & 0.811 & 0.913 \\
\hline IE & $0.708^{\mathrm{a}}$ & 0.021 & 0.667 & 0.749 \\
\hline PL & $0.826^{\mathrm{a}}$ & 0.013 & 0.801 & 0.850 \\
\hline SE & $0.691^{\mathrm{a}}$ & 0.029 & 0.634 & 0.749 \\
\hline SI & $1.085^{\mathrm{a}}$ & 0.029 & 1.028 & 1.142 \\
\hline UK & $0.860^{\mathrm{a}}$ & 0.018 & 0.826 & 0.895 \\
\hline Common view & $0.816^{\mathrm{a}}$ & 0.009 & 0.799 & 0.833 \\
\hline \multicolumn{5}{|c|}{ Moderate alkalinity } \\
\hline BE-FL & $0.900^{\mathrm{a}}$ & 0.037 & 0.827 & 0.972 \\
\hline $\mathrm{DE}$ & $0.914^{\mathrm{a}}$ & 0.038 & 0.839 & 0.989 \\
\hline FI & $0.662^{\mathrm{a}}$ & 0.028 & 0.606 & 0.718 \\
\hline FR & $1.076^{\mathrm{a}}$ & 0.025 & 1.026 & 1.126 \\
\hline IE & $0.911^{\mathrm{a}}$ & 0.024 & 0.863 & 0.959 \\
\hline IT & $0.774^{\mathrm{a}}$ & 0.054 & 0.668 & 0.880 \\
\hline SE & $0.859^{\mathrm{a}}$ & 0.032 & 0.796 & 0.921 \\
\hline UK & $0.834^{\mathrm{a}}$ & 0.024 & 0.787 & 0.880 \\
\hline Common view & $0.866^{\mathrm{a}}$ & 0.012 & 0.843 & 0.889 \\
\hline
\end{tabular}


Table 4. Average values for status class boundaries, expressed as TI-EQR, for high and moderate alkalinity European lakes

\begin{tabular}{ccccc}
\hline \multirow{2}{*}{ Lake type } & \multicolumn{4}{c}{ Boundary } \\
& High/Good & Good/Moderate & Moderate/Poor & Poor/Bad \\
\hline High alkalinity & 0.965 & 0.790 & 0.604 & 0.416 \\
Moderate alkalinity & 0.849 & 0.588 & 0.309 & 0.025 \\
\hline
\end{tabular}


Table 5. Indicator species for high, good and moderate status in moderate alkalinity lakes. Only taxa found in $\geq 10 \%$ of sites and with a maximum relative abundance $\geq 5 \%$ are included. Status classes are defined from the mean location of the national boundaries, calculated using the ICM, adjusted using national offsets. (Luc, can you check these tables and, in particular, look at the taxa highlighted in yellow which appear twice)

\begin{tabular}{|c|c|c|c|c|c|c|c|c|}
\hline Taxon name & IV & Mean & stdev & probability & Consistency & $\begin{array}{l}\text { Average } \\
\text { RA }\end{array}$ & $\begin{array}{l}\text { Maximum } \\
\text { RA }\end{array}$ & status \\
\hline Achnanthidium minutissimum (Kützing) Czarnecki & 61 & 32.5 & 1.1 & 0.0002 & 84.5 & 33.9 & 95.7 & $\mathrm{H}$ \\
\hline Cymbella affinis Kützing & 38.7 & 10.5 & 1.16 & 0.0002 & 19.0 & 2.0 & 17.8 & $\mathrm{H}$ \\
\hline Denticula tenuis Kützing & 34.9 & 7.2 & 0.91 & 0.0002 & 21.7 & 2.7 & 20.3 & $\mathrm{H}$ \\
\hline Cymbella helvetica Kützing & 20 & 5.2 & 0.82 & 0.0002 & 16.2 & 2.2 & 17.8 & $\mathrm{H}$ \\
\hline Nitzschia lacuum Lange-Bertalot & 16.2 & 7.2 & 0.9 & 0.0002 & 10.7 & 2.4 & 15.3 & $\mathrm{H}$ \\
\hline Brachysira vitrea (Grunow) Ross & 9.1 & 2.6 & 0.65 & 0.0002 & 20.7 & 1.9 & 9.2 & $\mathrm{H}$ \\
\hline Brachysira microcephala (Grunow) Compère & 8.1 & 2.7 & 0.59 & 0.0002 & 32.8 & 7.0 & 55.4 & $\mathrm{H}$ \\
\hline Fragilaria tenera (W. Smith) Lange-Bertalot & 7.4 & 3.4 & 0.7 & 0.0002 & 19.3 & 1.4 & 8.7 & $\mathrm{H}$ \\
\hline Fragilaria gracilis $\varnothing$ strup & 3.9 & 1.7 & 0.48 & 0.0012 & 15.5 & 6.2 & 40.2 & $\mathrm{H}$ \\
\hline Achnanthes laevis $\emptyset$ strup & 3.2 & 1.6 & 0.46 & 0.0058 & 15.9 & 1.0 & 6.1 & $\mathrm{H}$ \\
\hline Rossithidium pusillum (Grunow.) Round \& Bukhtiyarova & 3.2 & 1.2 & 0.39 & 0.0006 & 19.7 & 1.2 & 6.6 & $\mathrm{H}$ \\
\hline $\begin{array}{l}\text { Psammothidium helveticum (Hustedt) Bukhtiyarova \& } \\
\text { Round }\end{array}$ & 2.3 & 1.2 & 0.4 & 0.0164 & 14.5 & 2.2 & 15.7 & $\mathrm{H}$ \\
\hline Tabellaria fenestrata (Lyngbye) Kutzing & 1.2 & 0.6 & 0.28 & 0.0438 & 10.7 & 2.1 & 16.5 & $\mathrm{H}$ \\
\hline Epithemia adnata (Kutzing) Brébisson & 36.4 & 16.3 & 1.44 & 0.0002 & 14.5 & 1.1 & 9.8 & G \\
\hline Fragilaria pinnata Ehrenberg & 32 & 20.9 & 1.4 & 0.0002 & 11.0 & 5.4 & 21.8 & $\mathrm{G}$ \\
\hline Fragilaria construens (Ehrenberg) Grunow & 31.6 & 22.5 & 1.37 & 0.0002 & 10.3 & 4.0 & 22.7 & G \\
\hline Epithemia sorex Kützing & 27.6 & 15.3 & 1.34 & 0.0002 & 11.7 & 2.2 & 18.3 & G \\
\hline Navicula radiosa Kützing & 27.5 & 17.7 & 1.59 & 0.0002 & 39.0 & 1.1 & 6.3 & G \\
\hline Cymbella cymbiformis Agardh & 14.4 & 10.6 & 1.31 & 0.0084 & 13.1 & 1.6 & 18.2 & G \\
\hline Encyonopsis subminuta Krammer \& Reichardt & 14.4 & 6.5 & 0.89 & 0.0002 & 22.8 & 6.4 & 31.8 & G \\
\hline Tabellaria flocculosa (Roth) Kützing & 13 & 8.1 & 1.21 & 0.0022 & 67.6 & 6.2 & 51.5 & G \\
\hline Rhoicosphenia abbreviata (C. Agardh) Lange-Bertalot & 47.2 & 19 & 1.48 & 0.0002 & 15.9 & 4.2 & 52.1 & M \\
\hline Cocconeis placentula Ehrenberg & 40.5 & 29.4 & 1.8 & 0.0002 & 45.9 & 2.3 & 31.2 & M \\
\hline Nitzschia dissipata (Kützing) Grunow & 34.6 & 17.6 & 1.85 & 0.0002 & 35.9 & 1.7 & 16.3 & $M$ \\
\hline
\end{tabular}




\begin{tabular}{|c|c|c|c|c|c|c|c|c|}
\hline Taxon name & IV & Mean & stdev & probability & Consistency & $\begin{array}{l}\text { Average } \\
\text { RA }\end{array}$ & $\begin{array}{l}\text { Maximum } \\
\text { RA }\end{array}$ & status \\
\hline Nitzschia amphibia Grunow & 33.3 & 15.3 & 1.16 & 0.0002 & 10.0 & 3.7 & 52.8 & M \\
\hline Amphora pediculus (Kützing) Grunow & 29.3 & 20.9 & 1.3 & 0.0002 & 34.1 & 1.5 & 11.7 & M \\
\hline Gomphonema parvulum (Kützing) Kützing & 28.5 & 15.4 & 1.42 & 0.0002 & 45.9 & 2.3 & 38.1 & M \\
\hline Synedra ulna (Nitzsch) Ehrenberg & 27.4 & 15.7 & 1.42 & 0.0002 & 20.3 & 0.9 & 7.7 & M \\
\hline Fragilaria vaucheriae (Kützing) Petersen & 27.1 & 18.4 & 1.5 & 0.0002 & 46.9 & 4.4 & 45.7 & M \\
\hline $\begin{array}{l}\text { Planothidium lanceolatum (Brébisson ex Kützing) Lange- } \\
\text { Bertalot }\end{array}$ & 27.1 & 9.6 & 1.01 & 0.0002 & 27.2 & 1.7 & 22.4 & M \\
\hline Nitzschia paleacea (Grunow) Grunow in van Heurck & 27 & 9.6 & 1.25 & 0.0002 & 16.6 & 1.8 & 8.5 & M \\
\hline Nitzschia fonticola Grunow in Cleve et Möller & 25 & 12.6 & 1.36 & 0.0002 & 31.4 & 2.4 & 37.3 & M \\
\hline Nitzschia palea (Kützing) W.Smith & 24.7 & 9 & 1.08 & 0.0002 & 45.2 & 1.4 & 15.1 & M \\
\hline Navicula capitatoradiata Germain & 23 & 12.9 & 1.2 & 0.0002 & 13.1 & 0.8 & 7.4 & M \\
\hline Navicula gregaria Donkin & 18.1 & 7.3 & 1.07 & 0.0002 & 24.8 & 2.0 & 23.2 & M \\
\hline Amphora pediculus (Kützing) Grunow & 14.6 & 9.3 & 0.95 & 0.0004 & 34.1 & 1.5 & 11.7 & M \\
\hline Navicula cryptocephala Kützing & 14.4 & 9.4 & 1.25 & 0.0018 & 32.8 & 1.4 & 14.3 & M \\
\hline Gomphonema parvulum var. micropus (Kützing) Cleve & 9 & 3.5 & 0.69 & 0.0002 & 12.1 & 1.1 & 8.8 & M \\
\hline Navicula lanceolata (Agardh) Ehrenberg & 5.9 & 3.4 & 0.61 & 0.0022 & 10.0 & 1.0 & 7.0 & M \\
\hline Diadesmis confervacea Kützing & 1.2 & 0.4 & 0.22 & 0.0112 & 21.7 & 2.7 & 20.3 & M \\
\hline
\end{tabular}


Table 6. Indicator species for high, good and moderate status in high alkalinity lakes. Only taxa found in $\geq 10 \%$ of sites and with a maximum relative abundance $\geq 5 \%$ are included. Status classes are defined from the mean location of the national boundaries, calculated using the ICM, adjusted using national offsets.

\begin{tabular}{|c|c|c|c|c|c|c|c|c|}
\hline Taxon name & IV & Mean & stdev & prob & Consistency & $\begin{array}{c}\text { Average } \\
\text { RA }\end{array}$ & $\begin{array}{c}\text { Maximum } \\
\text { RA }\end{array}$ & status \\
\hline Achnanthidium minutissimum (Kützing) Czarnecki & 55.2 & 35 & 1.98 & 0.0002 & 78.5 & 11.5 & 96.9 & $\mathrm{H}$ \\
\hline Tabellaria flocculosa (Roth) Kützing & 42.2 & 29.8 & 4.86 & 0.0228 & 19.6 & 1.2 & 36.4 & $\mathrm{H}$ \\
\hline Gomphonema angustum ag. & 38.4 & 26 & 5.02 & 0.025 & 48.0 & 3.0 & 87.5 & $\mathrm{H}$ \\
\hline Denticula tenuis Kützing & 23.6 & 12.3 & 3.73 & 0.0188 & 14.0 & 1.6 & 41.8 & $\mathrm{H}$ \\
\hline Cymbella affinis Kützing & 18.5 & 10.9 & 3.51 & 0.0388 & 17.3 & 3.5 & 50.0 & $\mathrm{H}$ \\
\hline Brachysira vitrea (Grunow) Ross & 17.8 & 10.8 & 3.43 & 0.0454 & 6.1 & 1.0 & 11.0 & $\mathrm{H}$ \\
\hline Navicula cryptocephala Kutzing & 30.2 & 17 & 4.21 & 0.014 & 26.1 & 1.6 & 78.0 & G \\
\hline Nitzschia fonticola Grunow in Cleve et Möller & 28.5 & 16.9 & 4.38 & 0.0254 & 28.2 & 2.7 & 44.6 & G \\
\hline $\begin{array}{l}\text { Planothidium lanceolatum (Brébisson ex Kützing) } \\
\text { Lange-Bertalot }\end{array}$ & 26.9 & 16.1 & 4.1 & 0.0236 & 21.6 & 1.9 & 26.5 & G \\
\hline Amphora pediculus (Kützing) Grunow & 26.2 & 15.3 & 3.91 & 0.0224 & 86.1 & 5.3 & 59.7 & G \\
\hline Nitzschia lacuum Lange-Bertalot & 22.5 & 7.5 & 2.96 & 0.0028 & 12.2 & 1.1 & 9.8 & G \\
\hline Achnanthes clevei Grunow var. clevei & 21.3 & 11 & 3.59 & 0.0218 & 7.4 & 1.4 & 13.2 & G \\
\hline Epithemia sorex Kützing & 18.7 & 8.2 & 3.07 & 0.0126 & 43.2 & 3.0 & 49.1 & G \\
\hline Encyonopsis minuta Krammer \& Reichardt & 13.3 & 6.1 & 2.78 & 0.029 & 23.8 & 1.4 & 27.8 & G \\
\hline Navicula menisculus Schumann & 8.7 & 3.9 & 2.07 & 0.031 & 15.0 & 1.4 & 13.1 & G \\
\hline Encyonema reichardtii (Krammer) D.G. Mann & 6.8 & 2.9 & 1.75 & 0.031 & 1.8 & 1.3 & 11.6 & G \\
\hline Cymbella leptoceros (Ehrenberg) Kützing & 5.5 & 2.2 & 1.45 & 0.0276 & 7.7 & 0.7 & 7.3 & G \\
\hline Navicula gregaria Donkin & 65.9 & 13.6 & 4.12 & 0.0002 & 20.6 & 1.6 & 43.4 & M \\
\hline Gomphonema parvulum (Kützing) Kützing & 61.4 & 21.5 & 4.63 & 0.0002 & 39.5 & 1.5 & 56.4 & M \\
\hline Cocconeis placentula Ehrenberg & 55.3 & 27.4 & 4.77 & 0.0004 & 31.6 & 4.4 & 81.8 & M \\
\hline
\end{tabular}




\begin{tabular}{|c|c|c|c|c|c|c|c|c|}
\hline Taxon name & IV & Mean & stdev & prob & Consistency & $\begin{array}{l}\text { Average } \\
\text { RA }\end{array}$ & $\underset{\text { RA }}{\operatorname{Maximum}}$ & status \\
\hline Nitzschia palea (Kützing) W.Smith & 54.8 & 19.6 & 4.16 & 0.0002 & 25.4 & 3.3 & 88.2 & $\mathrm{M}$ \\
\hline Planothidium delicatulum (Kützing) & 34.4 & 5.5 & 2.49 & 0.0002 & 16.2 & 0.3 & 8.6 & M \\
\hline Nitzschia amphibia Grunow & 33.2 & 6.6 & 2.77 & 0.0002 & 47.4 & 1.4 & 63.6 & M \\
\hline Melosira varians Agardh & 31.3 & 4.9 & 2.38 & 0.0002 & 20.9 & 2.0 & 33.4 & M \\
\hline Nitzschia inconspicua Grunow & 28.1 & 6.4 & 2.72 & 0.0002 & 14.9 & 3.7 & 74.3 & M \\
\hline Eolimna minima (Grunow) Lange-Bertalot & 25.3 & 15.9 & 4.32 & 0.0382 & 18.2 & 1.8 & 51.8 & M \\
\hline $\begin{array}{l}\text { Rhoicosphenia abbreviata (C. Agardh) Lange- } \\
\text { Bertalot }\end{array}$ & 20.6 & 10.4 & 3.55 & 0.0198 & 56.1 & 2.5 & 59.4 & M \\
\hline Amphora veneta Kützing & 17.5 & 3.9 & 2.14 & 0.0012 & 10.5 & 5.0 & 68.7 & M \\
\hline $\begin{array}{l}\text { Planothidium frequentissimum (Lange-Bertalot) } \\
\text { Lange-Bertalot }\end{array}$ & 14.2 & 7.3 & 2.92 & 0.0338 & 33.6 & 0.5 & 14.9 & M \\
\hline Achnanthidium minutissimum (Kützing Czarnecki & 7.4 & 3.5 & 1.99 & 0.0496 & & & & M \\
\hline
\end{tabular}


All figures need to be redrawn. Are all needed?
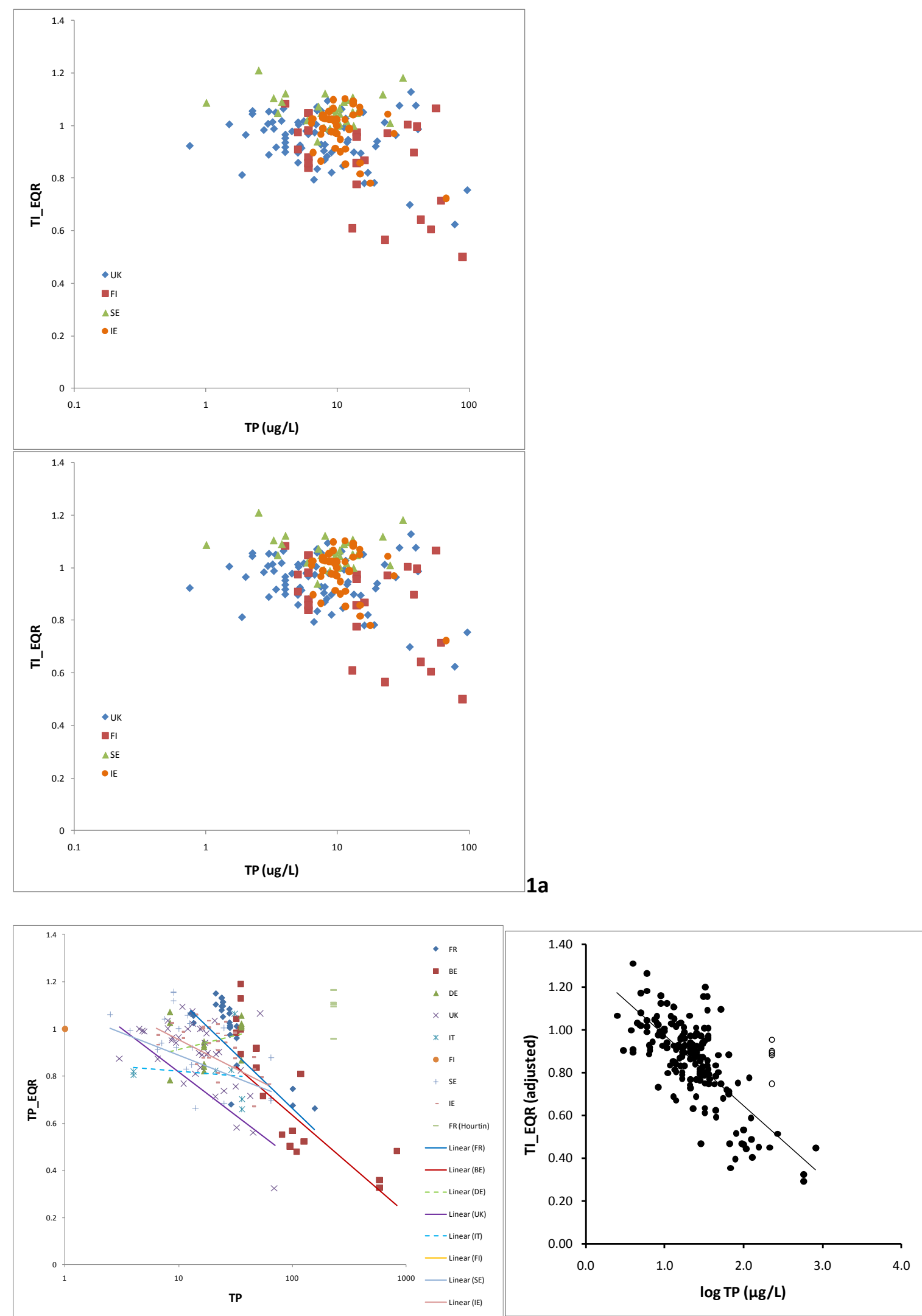

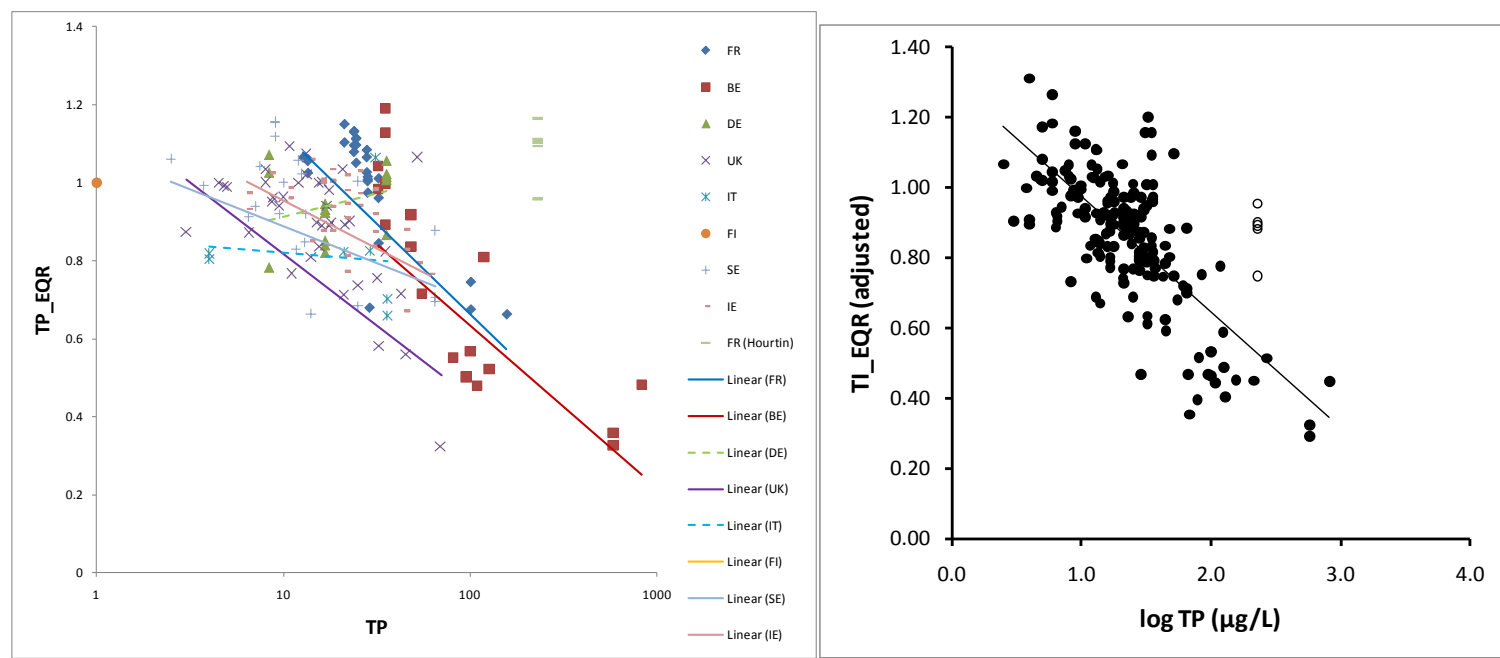

$1 b$

1c

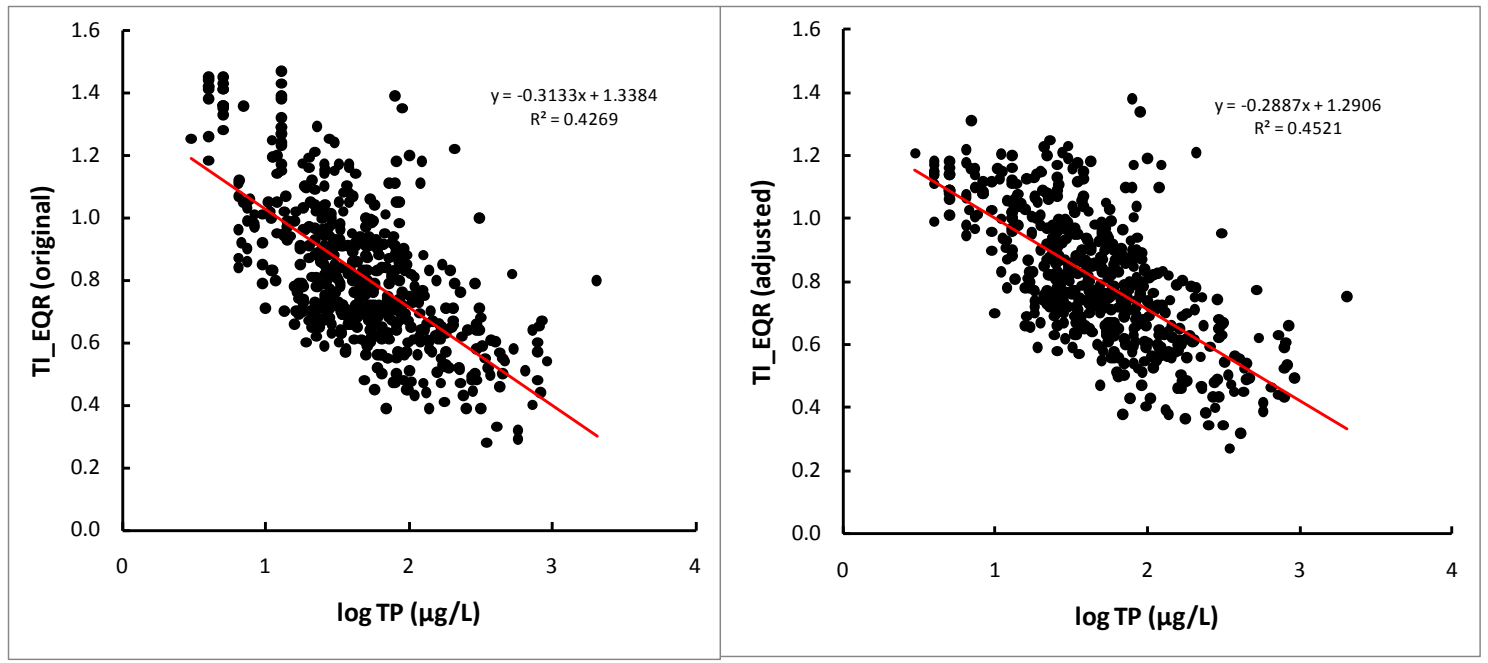

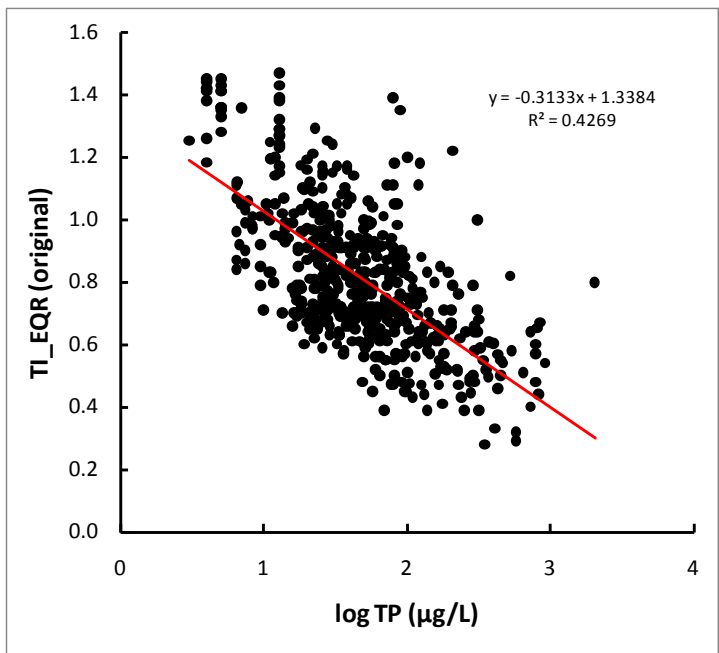

1d

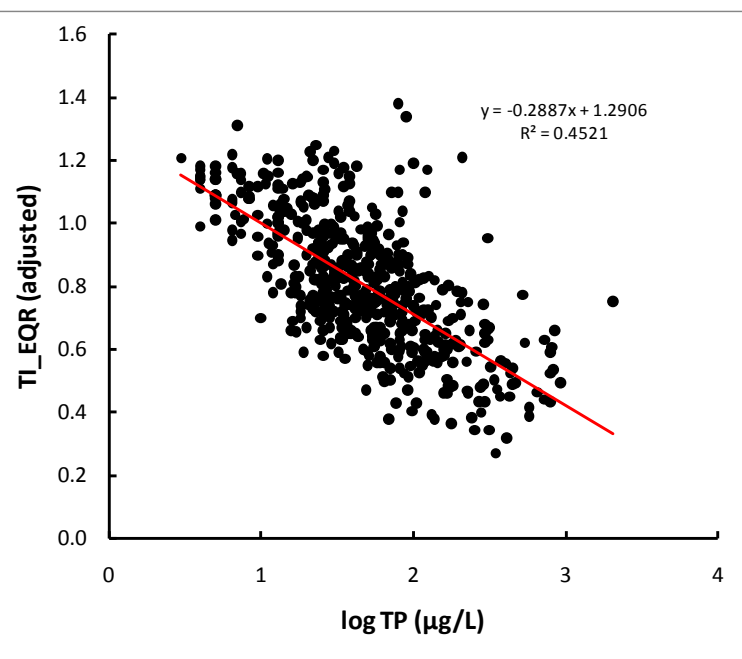

$1 e$

Fig. 2: pressure-response for a) LA; b \& c) MA (before/after adjustment) and d/e) HA (before/after) 


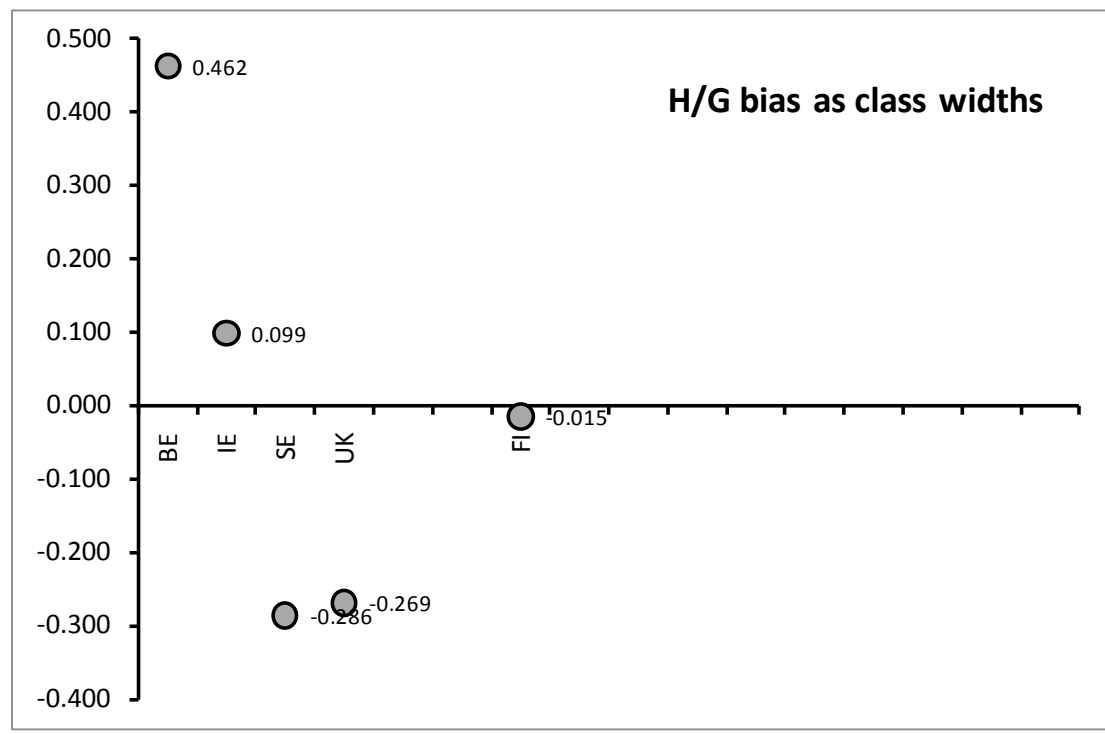

adjustment) 


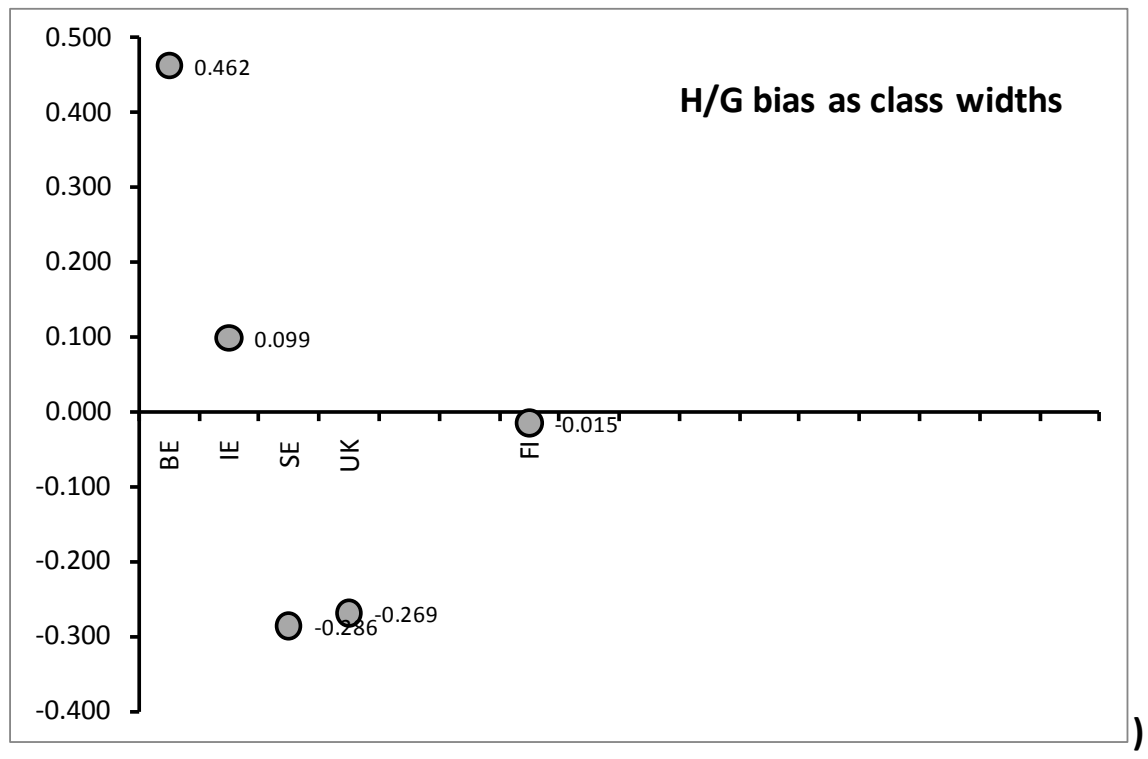




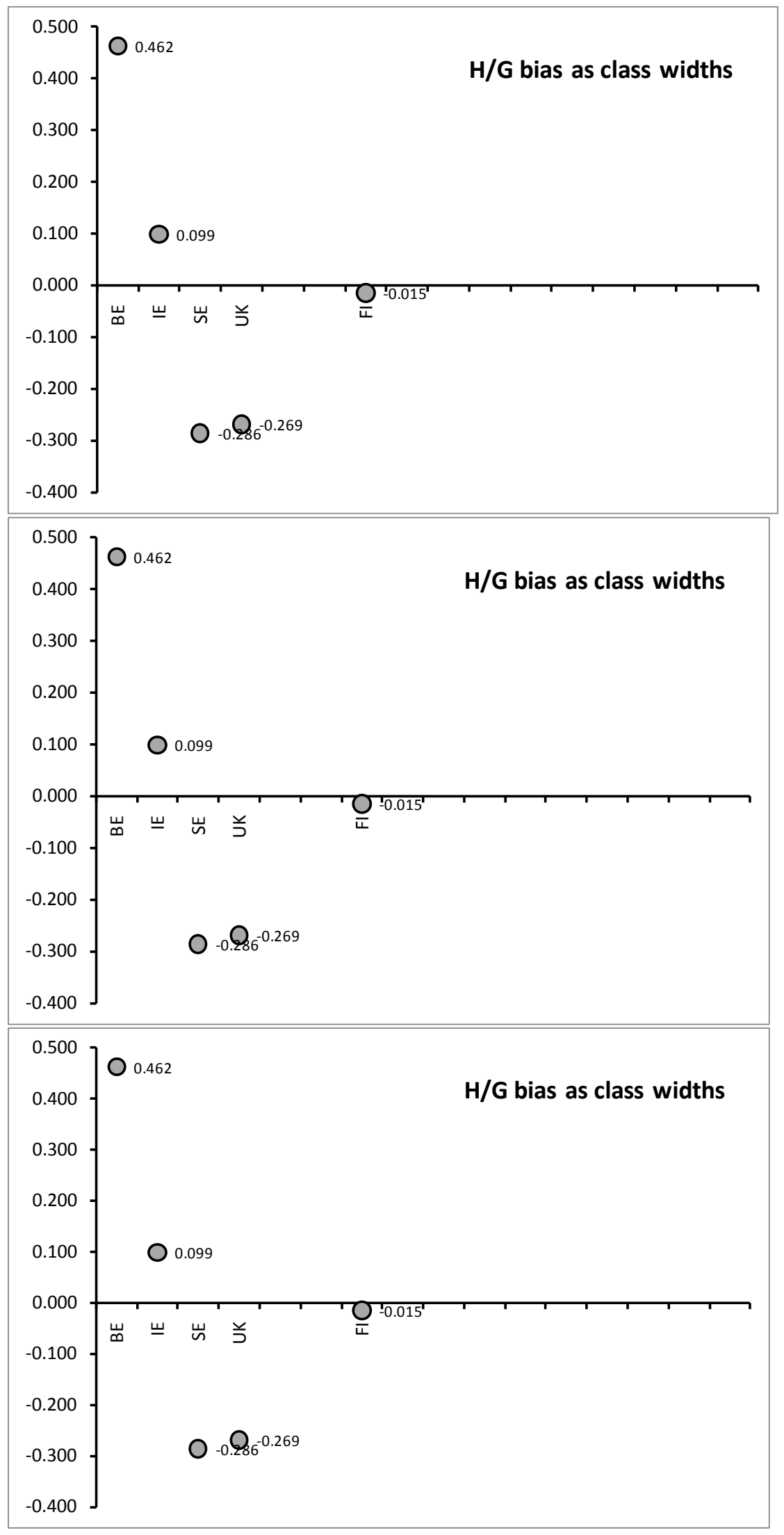



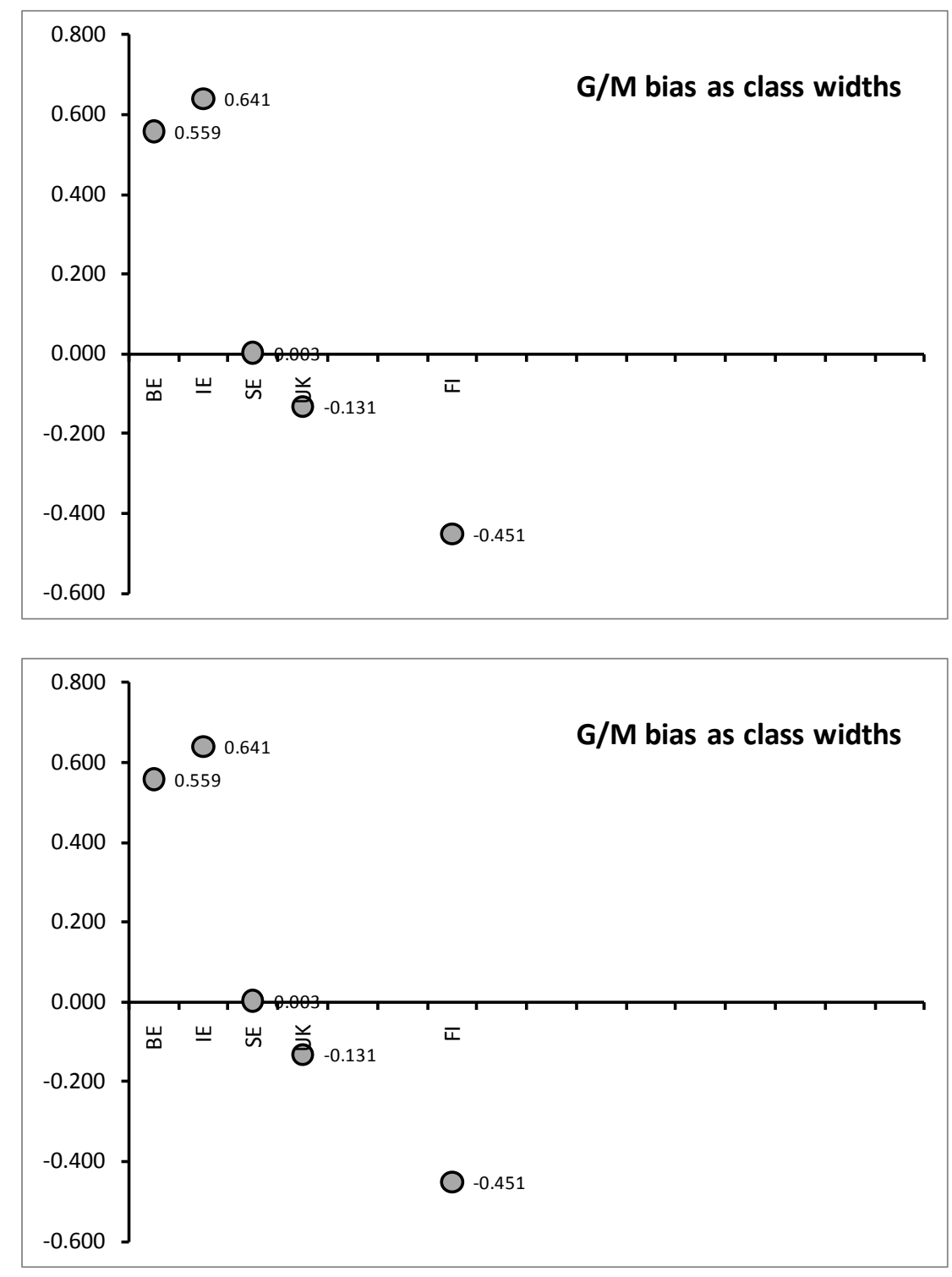

Fig. 2 a \& b: boundary variation as class width for MA lakes 

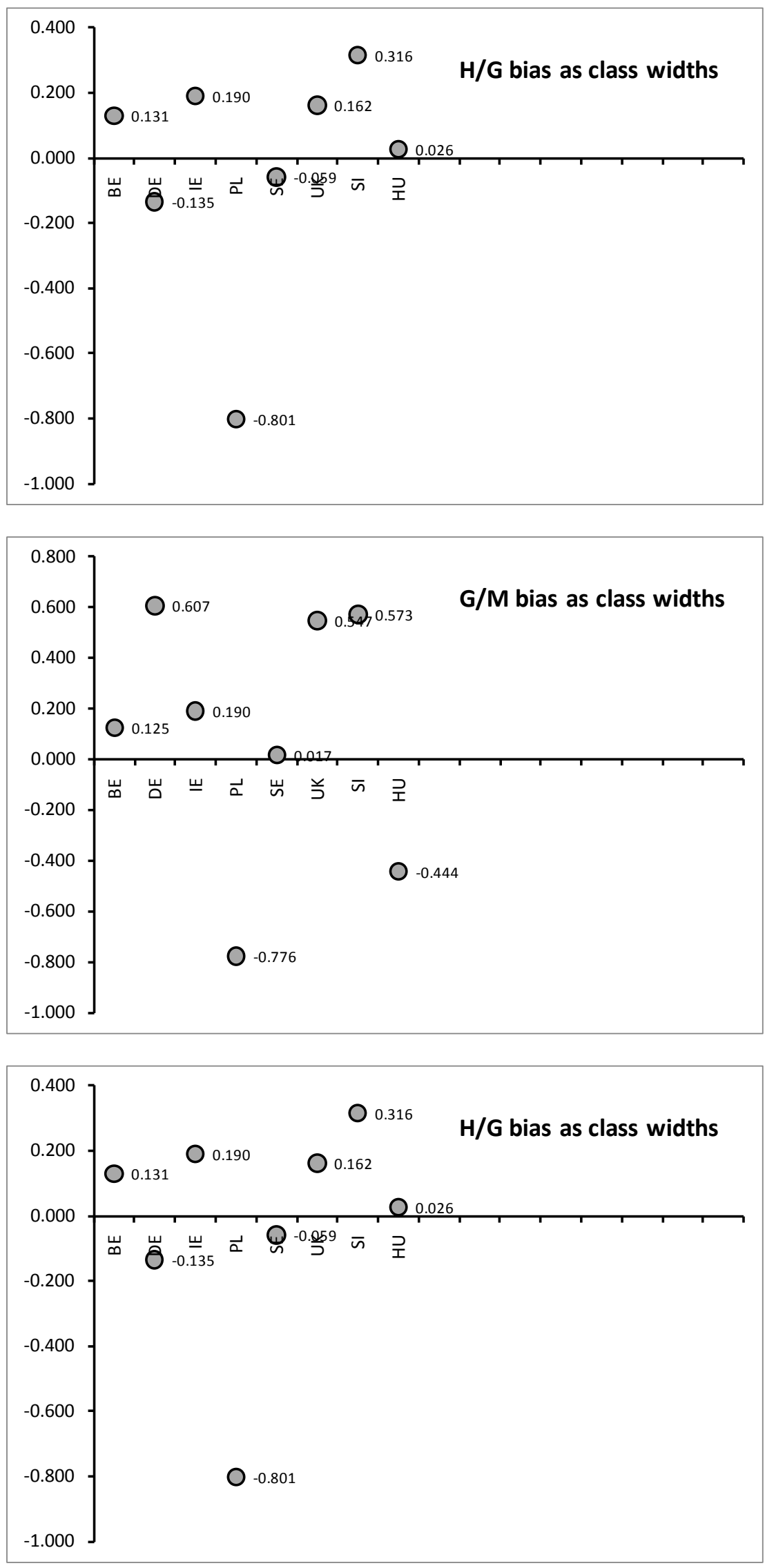


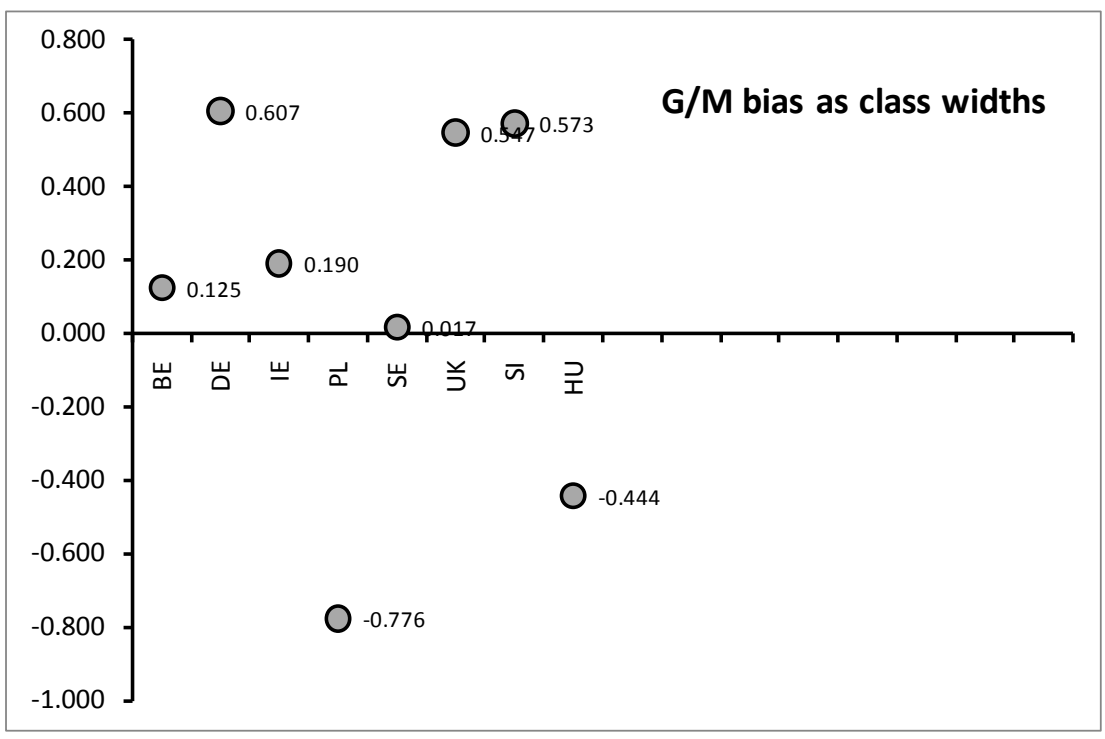

Fig. 2 c \& d: boundary variation as class width for HA lakes 
Fig. 3 (cont.). ENMI: Encyonema minutum; FCAP: Fragilaria capucina ag.; FVAU: Fragilaria vaucheriae ag.; GANT: Gomphonema angustum ag. 